OPEN ACCESS ISSN 2548-3501 (online)

Edited by:

Eny Maryanti

Reviewed by:

Dr. Basel J. A. ALi

${ }^{\star}$ Correspondence:

Received: April 2020

Accepted: June 2020

Published: 31 July 2020

Citation:

Ahmed ER, Alabdullah TTY and

Shaharudin MS (2020) Approaches

to Control Mechanisms and Their

Implications for Companies

Profitability: a Study in UAE.

Journal of accounting Science. 4:2.

doi: 10.21070/jas.v4i2.1010

\section{Approaches to Control Mechanisms and Their Implications for Companies' Profitability: a Study in UAE}

\section{Pendekatan untuk Mekanisme Kontrol dan Implikasinya untuk Profitabilitas Perusahaan: Studi di UEA}

\author{
Essia Ries Ahmed ${ }^{1}$, Tariq Tawfeeq Yousif Alabdullah ${ }^{2}$, Muhammad Shabir Shaharudin ${ }^{3}$ \\ ${ }^{1} 1$ Collage of Economics, Management and Information Systems, University of Nizwa, Oman, ${ }^{2}$ Accounting Department, \\ College of Administration and Economics, University of Basrah, Iraq, ${ }^{3}$ Faculty of Industrial Management, Universiti Malaysia \\ Pahang, Malaysia
}

This study tries to evaluate and test the role of control mechanisms represented by foreign ownership and insider ownership on companies' profitability in the listed companies in the UAE and whether independent variables are matter in determining the profitability of such companies. This study utilized companies belong to non-financial sector for the year of 2019 with a sample of 50 companies to be analyzed in the current study. To test the independent and dependent variables, regression analysis was used via using SPSS. The findings show that insider ownership has insignificant impact on companies' profitability . On the other hand, the findings revealed evidence to support the effect of foreign ownership on companies' profitability. Moreover, there is a insignificant evidence reflected the fact that companies' size has insignificant impact on companies' profitability. This study added further evidence in Dubai context where there is a rare and unique studies that have been done in this important context. It takes in tits account to investigate both insider and foreign ownership and their impact companies' profitability

Keywords: control mechanisms, companies' profitability, UEA.

Penelitian ini mencoba untuk mengevaluasi dan menguji peran mekanisme kontrol yang diwakili oleh kepemilikan asing dan kepemilikan orang dalam terhadap profitabilitas perusahaan di perusahaan yang terdaftar di UEA dan apakah variabel independen penting dalam menentukan profitabilitas perusahaan tersebut. Penelitian ini memanfaatkan perusahaan sektor non keuangan untuk tahun 2019 dengan jumlah sampel 50 perusahaan untuk dianalisis dalam penelitian ini. Untuk menguji variabel independen dan dependen digunakan analisis regresi dengan menggunakan SPSS. Temuan menunjukkan bahwa kepemilikan orang dalam memiliki pengaruh yang tidak signifikan terhadap profitabilitas perusahaan. Di sisi lain, temuan tersebut mengungkap bukti yang mendukung pengaruh kepemilikan asing terhadap profitabilitas perusahaan. Selain itu, terdapat bukti 
yang tidak signifikan yang mencerminkan fakta bahwa ukuran perusahaan memiliki pengaruh yang tidak signifikan terhadap profitabilitas perusahaan. Studi ini menambahkan bukti lebih lanjut dalam konteks Dubai di mana terdapat studi langka dan unik yang telah dilakukan dalam konteks penting ini. Diperlukan pertimbangan untuk menyelidiki kepemilikan orang dalam dan asing serta dampaknya terhadap profitabilitas perusahaan

Keywords: mekanisme kontrol, profitabilitas perusahaan, UEA. 


\section{INTRODUCTION}

Control mechanisms (CMs) are the practices and rules that govern the link between the owners, managers, and other stakeholders in any company Ahmed et al. (2020); Thottoli et al. (2019); Alabdullah et al. (2014). These mechanisms are very important for increasing the interests of the owners through controlling the events of the companies based on robust and transparent tools. CMs have positive impact on the stability of the financial markets by reinforcing market confidence, economic efficiency and integrity Alabdullah et al. (2018b); Abushammala et al. (2015); Alabdullah (2014) They help in increasing a good company performance in all sectors; financial and non-financial sectors Ahmed et al. (2020) . In emerging economies, there have been an intensive concern about the dire need for control mechanisms in all companies, especially after several failures and financial scandals that have happened around the world Zinser (2019); Hashim et al. (2019). Good control mechanisms have considered nowadays as a key factor in enhancing companies' performance, guaranteeing the rights for both insider and foreign investors, and in increasing the development of the economy Alabdullah (2020); Rahim et al. (2018, 2019) Overall, although there are a considerable interest and attention in such control mechanisms that have been given by developed economies, scarcity and lack of modern and contemporary studies exist in emerging economies and (2019). Several studies have examined the link between control mechanisms and company profitability Ahmed et al. (2020); Alabdullah (2020); Alharbi et al. (2018); Alabdullah et al. (2019); Alabdullah and Ahmed (2018) . It has been widely recognized by scholars that control mechanisms play a significant role in enhancing and improving corporate performance. In emerging economies, effective control mechanisms have got a priority due to that it might support positively the excellence of management and business assistance to eventually leads to attract local and international investors Marn \& Romuald (2012). Nonetheless, in emerging economies there is a weakness in both legal controls and investors protection as mentioned by Chen et al. (2011). For instance, Alabdullah (2018); Mishra and Mohanty (????); Chhaochharia and Grinstein (2007); Alabdullah et al. (2016); Dey (2008) have mentioned that control mechanisms can be considerably impacte by its control mechanisms. However, in Gulf Cooperation Council (GCC) countries and the United Arab Emirates (UAE) in particular, there is a lack of studies to examinee the control mechanisms and their impact on corporate profitability, which justifies the aim of this research. Academically, there have been limited studies in this regard in the context of emerging markets, and to date, there is still a dearth of studies on practices of control mechanisms in the context of the UAE. More specifically, as mentioned by Gross and Ghafar (2019) that although GCC countries, including Dubai, have many good features in several directions, and in spite of the expected fluctuations in energy and oil prices at the short and medium levels, the problem is that these countries are still fac- ing challenges and problems represented by their dire need to essentially reform their economies.

The current study is important for the reason that the world is unstable and needs to have further studies to be done, especially the world faced sudden pandemic (COVID-19 Crisis) that hit all the countries around the world Alabdullah et al, (2020). In that, humanity faces many problems and challenges, including poverty, climate change and, more recently, the pandemic of COVID-19. These challenging might be addressed via investigating a set of control mechanisms. In this work we will deal with the concept of investors on companies' profitability. Our analysis essential from the accounting and management perspective and from theoretical and empirical insights into how control mechanisms effect companies' profitability in listed companies in UAE.

The current research focused on the most recent studies related to control mechanisms and corporate performance, specifically it focused on the literature that has been done in the last three years. Companies are adopting control mechanisms to assure the companies' accountability to the shareholders and to enhance the financial reports transparency Tariq and Abbas (2013) . Control mechanisms is becoming a necessary subject in the business environment of UAE, and the debate on the development of the control mechanisms is of significant interest Aljifri and Moustafa (2007) . The role of control mechanisms is to improve and enhance corporate performance was investigated in the previous studies based on agency theory as a key variable which might succeed and strengthened as an important goal as mentioned by Alabdullah (2016a,e,c,d); Farhan et al. (2017) examine the effect of the control mechanisms on companies' profitability in the UAE and found that the control mechanisms are negatively affect companies' profitability. Although the empirical study that done by Aljifri and Moustafa (2007) was performed by using data of the UAE companies, they examined control mechanisms in their study, but they failed to address the mechanisms that have been imposed by the recent regulations. Also, Bahoo et al. (2019) in their study they focused on testing the impact of control mechanisms, represented by management ownership, on the companies' profitability and they found that multiple techniques could be suggested as an approach of the broader to the empirical analysis of performance and the also they dealt with the effect of control mechanisms and management ownership on companies' profitability. Al-Gamrh et al. (2020) tested the impact of investment opportunities on companies' profitability and they evaluate control mechanisms practices in the UAE. The findings of this study revealed that the level of control mechanisms practiced in the UAE is weak. Lode and Bajrei (2020) tested the link between control mechanisms and the level of information asymmetry in UAE and they found that control mechanisms have positive impact among UAE listed companies. Another study was done by Kuwaiti and A (2019) , he analyzed the influence of various control mechanisms in public listed companies on the profitability in the context of UAE. The results show that the control mechanisms are posi- 
tively affect companies' profitability. Nassar and Jreisat (2020) they attempt to test the compliance of control mechanisms rules and the findings showed that UAE companies comply with the application of control mechanisms rules. Al-Gamrh et al. (2020) tested the effect of two different types of control mechanisms by Arab and non-Arab investors on companies' profitability. As a result, they found that the Arab foreign ownership affects negatively the companies' profitability, while non-Arab foreign ownership has positive impact. Obaid and Amrah (2020) Analyzed the effectiveness of control mechanisms on earnings quality within Gulf cooperation council. The framework was suitable for assessing the level of EQ disclosed and the link between control mechanisms and earning quality was based on Gulf cooperation council policies. Ramli (2019) examined the interdependence among the risks in the presence of control mechanisms in banking sector listed in UAE. They focused on the main risks associated with control mechanisms, operational risk, credit risk, market risk, and liquidity risk against the bank's profitability. Ahmed (2017) tested whether the control mechanisms Index has an affect on financial profitability of Islamic banks in UAE. The find a positive link between control mechanisms Index and banks' profitability.

Based on the previous studies in the literature such as and (2019) shows that the ownership structure is considered as a success tool used by the companies in alleviating agency costs by controlling the opportunistic attitude of the managers. Several researches like Bahoo at el., (2019) Al-Gamrh et al. (2020) examined the link between ownership structure and companies' profitability and the findings were varying. Some studies indicate that ownership' element is an important variable that affects the level of companies' profitability Alabdullah et al. (2018b,a); Alabdullah (2016e)

Based on the above, previous studies show that foreign ownership and insider ownership have effective role in monitoring the company and enhancing company profitability. Based on that, the present study developed these hypotheses:

$\mathrm{H} 1$ : A positive link between insider ownership and companies' profitability (ROA).

$\mathrm{H} 2$ : A positive link between foreign ownership and companies' profitability(ROA).

H3: A positive link between insider ownership and companies' profitability(ROE).

H4: A positive link between foreign ownership and companies' profitability(ROE).

\section{METHOD}

\section{Data Collection \& Measurement}

This study chose a sample of non-financial sector's companies listed in Dubai via collecting data using annual reports for the year 2019. The accounting and non-accounting data were collected from the website of UAE Stock Exchange for 50 nonfinancial firms that would be useful for reaching the target and aim of the present study. Our study is a cross sectional for one year to test its hypotheses and to know the relations between all the variables, the dependent and independent variables. Where inside and foreign ownership were the dependent variables and both return on assets (ROA) and return on equity (ROE) are dependent variables used in the current work and the analysis was done by using SPSS.

Table 1 shows the measurement of the variables. on the following page presents a summary of the measurement of variables.

[Table 1 about here.]

\section{Models of the study}

They involve several variables, with the insider ownership and foreign ownership that might have probable effect on profitability; In that, they might strongly effect both ROA and ROE. To test these relations in one of the developing countries, namely UAE, a cross-sectional analysis was done by using real data could be reached by the annual reports for the year 2019 . The models are explained by the below equations:

$$
\begin{aligned}
& R O A=\alpha+\beta 1 I N O+\beta 2 F R O+\beta 3 F Z \\
& R O E=\alpha+\beta 1 I N O+\beta 2 F R O+\beta 3 F Z
\end{aligned}
$$

\section{RESULTS}

\section{Descriptive Analysis}

It is for all the variables used by the current study including both dependent and independent variables for 50 nonfinancial firms listed at Dubai Stock Exchange. The distribution of the Analysis is shown in Table 2

The Table showed that the values for kurtosis $(\mathrm{K})$ and skewness(S) illustrate that sample of the study is distributed in normal way because the values are in the accepted level of skewness(S) and kurtosis(K). As explained by Alabdullah et al. (2014), that the data can be considered as normal data when the standard (K) is \pm 3 and the standard of $(\mathrm{S})$ is \pm 1.96 .

[Table 2 about here.]

\section{Correlation Analysis}

Table 3 refers correlation test between all the dependent variables. It revealed that the link between independent variables; insider ownership (INO) and foreign ownership (FRO) shows a negative relation with value of (BOD-0.369), which means no multicollinearity problem between the IVS.

[Table 3 about here.]

Level of significance ${ }^{\star} \mathrm{p}<0.05,{ }^{\star *} \mathrm{p}<0.01$ 


\section{Regression Test}

It is for the aim of testing the relation between the IVs and CVs, as a common statistical method that utilized in several studies in science fields Alabdullah (2016b) .

\section{Regression for Model 1}

The results on profitability via ROA in Model 1 is explained above is:

$$
R O A=\alpha+\beta 1 I N O+\beta 2 F R O+\beta 3 F Z
$$

The results revealed that $\mathrm{R}$ square is 0.145 for ROA. This means $\mathrm{R}$ square give explanation with 14 percent the IVS INO and FRO on the DV of ROA, and also the F change in this model is 0.033 .

Also when we run the regression, the results show that insider ownership (INO) has an in insignificant relation with the ROA with $t$-value of 1.623 and $p$ value with 0.111 . Nonetheless, foreign ownership (FRO) has a positive link with ROA with t-value of 2.624 and P-value with 0.012 measure with sig. level of ${ }^{* *} \mathrm{p}<0.05,{ }^{* * *} \mathrm{p}<0.01$.

our work drew a hypothesis that says there is a positive link between insider ownership,foreign ownership and companies' profitability (ROA). The findings show that there is an insignificant relation between INO and ROA because $\mathrm{t}$-value $=1.623$, $\mathrm{P}<0.1$ and this result is not in line with the previous studies that have been done previously in the literature. Therefore, hypothesis H1 (a positive link between insider ownership and companies' profitability (ROA) is not supported. . On the other hand, the results reveal that there is a positive link between FRO and ROA, which means that $\mathrm{H} 2$ : (a positive link between foreign ownership and companies' profitability(ROA) is supported because $(\mathrm{T}$-value $=2.624, \mathrm{P}<0.1)$.

\section{Regression Results of Model 2}

The results on profitability via ROA in Model 1 is explained above is:

$$
R O E=\alpha+\beta 1 I N O+\beta 2 F R O+\beta 3 F Z
$$

However, the current work is not going to deal with any details about this model due to the fact that the results of ANOVA test shows this model is not Sig. with Sig. value of 0.453 .

\section{REFERENCES}

Abushammala, S. N., Alabdullah, T. T. Y., and Ahmed, E. R. (2015). Causal Relationship between Market Growth and Economic Growth. Comparison Study. European Journal of Business and Management 7, 31-36.

Ahmed, E. R., Alabdullah, T. T. Y., .Thottoli, M. M., and Maryanti, E. (2020). Does Corporate Governance Predict Firm Profitability? An Empirical Study in Oman.

\section{CONCLUSION}

This study tests the impact of two sets of internal control mechanisms variables related to ownership structure -foreign ownership and insider ownership- and their impact on companies' profitability. Recently, the internal control mechanisms system has been considered as a very significant issue to all firms including financial and non-financial sectors and their profitability. Globally, the business has faced many failures and scandals at the level of the financial sectors such as Marconi and Enron and Arthur Andersen. Such scandals and other financial crises all have brought about a shock for developing economics and given so much attention to stakeholders and investors to beware of dealing with firms, within financial and non-financial sectors, which have a poor level of control mechanisms system. Some studies have dealt with the link between control mechanisms and companies' profitability; however, it should be noted that while the argument over mechanisms of corporate governance role has been rich in rhetoric. There have been a few empirical analysis that have tested the link between control mechanisms and companies' profitability by choosing ROE and ROA as a measurement of performance in dealing with UAE financial and non-financial sectors.

The present work investigated the effect of the control mechanisms on the profitability of the non-financial sectors' companies. The findings of the current study in general suggest adopting structures of internal control mechanisms for its value implications for the emerging economics' countries, especially in UAE non-financial sectors. The UAE practices and regulations of internal control mechanisms, as well as the literature review preceding it, have significant policy implications for the competitiveness of financial markets in UAE. UAE's internal control mechanisms system is in line with international practices, demonstrating that the sound practice of control mechanisms is portable across borders. The current study outstandingly investigated its control mechanisms and linked them to companies' profitability. The current research revealed that there a positive relationship between foreign ownership and profitability by using indicators for measuring companies.

\section{ACKNOWLEDGMENT}

The Authors wish to acknowledge Eny Maryanti From Universitas Muhammadiyah Sidoarjo Indonesia for her assistance in publishing this paper, her help is greatly appriciated. 
Alabdullah, T. T. Y. (2014). Corporate Governance Development: New or Old Concept? Corporate Governance, 6-6.

Alabdullah, T. T. Y. (2016a). Agency cost and management behavior: The role of performance as a moderator. The Role of Performance as a Moderator vol. 5, 5, $1858-1864$.

Alabdullah, T. T. Y. (2016b). Agency Theory Perspective: A Quantitative Study Of Accounting Performance Measures In Emerging Economies. In ICTE Proceedings.

Alabdullah, T. T. Y. (2016c). Are Board Size And Ownership Structure Beneficial In Emerging Markets' Firms? Evidence From Jordan. International Journal of Management \& Information Systems (IJMIS) 20, 87-94. doi: 10.19030/ijmis.v20i3. 9752.

Alabdullah, T. T. Y. (2016d). Corporate governance from the perspective of the past and the present and the need to fill an international GAP. Risk Governance and Control: Financial Markets and Institutions 6, 96-101. doi: 10.22495/ rcgv6i4art12.

Alabdullah, T. T. Y. (2016e). The Performance of Companies and The Board's Characteristics From The New Perspective of Manipulation Avoidance. Corporate Ownership and Control 13, 279-286. doi: 10.22495/cocv13i4c2p1.

Alabdullah, T. T. Y. (2018). The relationship between ownership structure and firm financial performance. Benchmarking: An International Journal 25, 319-333. doi: 10.1108/bij-04-2016-0051.

Alabdullah, T. T. Y. (2020). Management accounting insight via a new perspective on the risk management - companies' profitability relationship. International Journal of Intelligent Enterprise 7.

Alabdullah, T. T. Y. and Ahmed, E. R. (2018). Corporate Governance: To What Extent it is important in the Arab Countries. International Journal of Science and Research 7.

Alabdullah, T. T. Y., Ahmed, E. R., and Muneerali, M. (2019). Effect of Board Size and Duality on Corporate Social Responsibility: What has Improved in Corporate Governance in Asia? Journal of Accounting Science 3, 121-135.

Alabdullah, T. T. Y., Ahmed, E. R., and Yahya, S. (2018a). The Determination of Firm Performance in Emerging Nations: Do Board Size and Firm Size Matter? International Academic Journal of Accounting and Financial Management 05, 5766. doi: $10.9756 /$ iajafm/v5i2/1810017.

Alabdullah, T. T. Y., Laadjal, A., Ahmed, E. R., and Al-Asadi, Y. A. A. (2018b). Board Features and Capital Structure in Emerging Markets. Journal of Advanced Management Science 6, 74-80. doi: 10.18178/joams.6.2.74-80.

Alabdullah, T. T. Y., Yahya, S., Nor, M. I., and Majeed, F. Q. (2016). An investigation of corporate governance from a new perspective: Examining the financial performance of companies and the impact of executive turnover. Corporate Board role duties and composition 12, 53-69. doi: 10.22495/cbv12ilart6.

Alabdullah, T. T. Y., Yahya, S., and Ramayah, T. (2014). Corporate Governance Mechanisms and Jordanian Companies' Financial Performance. Asian Social Science 10, 247-247. doi: 10.5539/ass.v10n22p247.

Alharbi, R. K., Yahya, S. B., and Ahmed, E. R. (2018). Characteristics of Manager's and SMEs Performance: The Role of Access to Finance as a Moderator. International Journal of Engineering \& Technology 7, 5115-5119.

Aljifri, K. and Moustafa, M. (2007). The Impact of Corporate Governance Mechanisms on the Performance of UAE Firms: An Empirical Analysis. Journal of Economic and Administrative Sciences 23, 71-93. doi: 10.1108/10264116200700008.

and, T. A. (2019). Management Accounting and Service Companies' Performance: Research in Emerging Economies. Australasian Accounting, Business and
Finance Journal 13, 100-118. doi: 10.14453/aabfj.v13i4.8.

Chhaochharia, V. and Grinstein, Y. (2007). Corporate Governance and Firm Value: The Impact of the 2002 Governance Rules. The Journal of Finance 62, 1789-1825. doi: $10.1111 /$ j.1540-6261.2007.01257.x.

Dey, A. (2008). Corporate governance and agency conflicts. Journal of Accounting Research 46, 1143-1181.

Farhan, A., Obaid, S. N., and Azlan, H. (2017). Corporate Governance Effect On Firms' Performance - Evidence From The Uae. Journal of Economic and Administrative Sciences 33, 66-80. doi: 10.1108/jeas-01-2016-0002.

Hashim, F., Ahmed, E. R., and Huey, Y. M. (2019). Board Diversity and Earning Quality: Examining the Role of Internal Audit as a Moderator. Business and Finance Journal 13, 73-91.

Kuwaiti, A. and A, A. Y. A. S. (2019).

Lode, N. A. and Bajrei, S. S. S. (2020). Are Corporate Governance Mechanisms Associated With Information Asymmetry Level Among UAE Listed Companies? Journal of Business Management and Accounting 8, 105-115.

Mishra, S. and Mohanty (????). Corporate governance as a value driver for firm performance: evidence from India. Corporate Governance 14, 1-25.

Nassar, M. and Jreisat, A. (2020). The Application of Corporate Governance Rules in the UAE. International Journal of Economics and Business Research 19, 223-244.

Obaid, M. M. and Amrah, M. R. (2020). Emerging policies and the effectiveness of corporate governance mechanisms on earning quality. International Journal of Research in Business and Social Science (2147-4478) 9, 157-164. doi: 10.20525/ijrbs.v9i3.691.

Rahim, A., Ahmed, N. F., Sarkawi, E. R., Jaafar, M. N., Shams.uddin, A. R., and $J$ (2019). Operational risk management and customer complaints: the role of product complexity as a moderator. Benchmarking: An International Journal 26, 2486-2513.

Rahim, N. F. A., .Ahmed, E. R., and Faeeq, M. K. (2018). Internal control system and perceived operational risk management in Malaysian conventional banking industry. Global Business and Management Research 10, 135-149.

Ramli, N. N. S. (2019). The Affect of Operational Ratio on Corporate Governance of Emirates Nbd in United Arab Emirates (UAE).

Tariq, Y. B. and Abbas, Z. (2013). Compliance and multidimensional firm performance: Evaluating the efficacy of rule-based code of corporate governance. Economic Modelling 35, 565-575. doi: 10.1016/j.econmod.2013.08.015.

Thottoli, M. M., Thomas, K. V., and Ahmed, E. R. (2019). Adoption of Audit Software by Audit Firms: A Qualitative Study. Journal of Information and Computational Science 9, 768-776.

Zinser, B. A. . (2019). Retail Islamic banking and financial services: Determinants of use by Muslims in the USA. Journal of Islamic Marketing 10, 168-190.

Conflict of Interest Statement: The authors declare that the research was conducted in the absence of any commercial or financial relationships that could be construed as a potential conflict of interest.

Copyright $(2020$ Ahmed, Alabdullah and Shaharudin. This is an open-access article distributed under the terms of the Creative Commons Attribution License (CC BY). The use, distribution or reproduction in other forums is permitted, provided the original author(s) and the copyright owner(s) are credited and that the original publication in this journal is cited, in accordance with accepted academic practice. No use, distribution or reproduction is permitted which does not comply with these terms. 


\section{LIST OF TABLES}

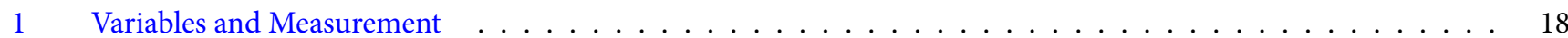

2 Descriptive Analysis . . . . . . . . . . . . . . . . . . . . . . . . . . . 19

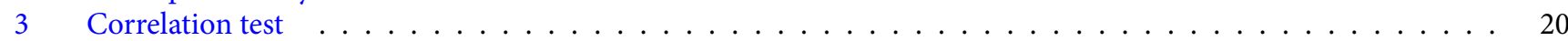


TABLE 1 | Variables and Measurement

\begin{tabular}{llll}
\hline No & Variables & Acr. & Measurement \\
\hline DVs & & & \\
1 & Return on Assets & ROA & Ratio of net income divided total assets. \\
2 & Return on Equity & ROE & Ratio of net income divided common equity. \\
IVs & & & \\
3 & Inside ownership & INO & The number of directors on the board of directors. \\
4 & Foreign ownership & IFO & Ratio of the share owned by foreign owners divided by total number of shares issued \\
5 & Company's Size & FZ & Natural logarithmic of the company's total assets. \\
\hline
\end{tabular}


TABLE 2 | Descriptive Analysis

\begin{tabular}{llllll} 
All-variables & Mean & Std Dev & Min & Max & Skewness(S) \\
ROA & 0.5694 & 1.122 & 0.100 & 4.400 & 1.976 \\
ROE & 1.217 & 2.590 & 0.000 & 10.000 & 2.303 \\
INO & 0.639 & 0.335 & 0.000 & 0.990 & -0.768 \\
FRO & 0.311 & 0.337 & 0.000 & 1.000 & 1.039 \\
FZ & 7.249 & 0.518 & 0.000 & 8.820 & -1.026 \\
-0.399 & 0.486 \\
\hline
\end{tabular}


TABLE 3 | Correlation test

INO
FRO
ROA
ROE
INO
1
FRO
$-0.369^{* *}$
1
0.109
0.091
$0.695^{\star *}$
1
ROA
0.108
$0.297^{\star}$
1

